\title{
Biochemical characterization of specific Alanine Decarboxylase (AlaDC) and its ancestral enzyme Serine Decarboxylase (SDC) in tea plants (Camellia sinensis)
}

Peixian Bai ${ }^{1,2 \dagger}$, Liyuan Wang ${ }^{1 \dagger}$, Kang Wei ${ }^{1}$, Li Ruan ${ }^{1}$, Liyun $\mathrm{Wu}^{1}$, Mengdi $\mathrm{He}^{1}$, Dejiang $\mathrm{Ni}^{2^{*}}$ and Hao Cheng ${ }^{1 *}$

\begin{abstract}
Background: Alanine decarboxylase (AlaDC), specifically present in tea plants, is crucial for theanine biosynthesis. Serine decarboxylase (SDC), found in many plants, is a protein most closely related to AlaDC. To investigate whether the new gene AlaDC originate from gene SDC and to determine the biochemical properties of the two proteins from Camellia sinensis, the sequences of CSAlaDC and CSSDC were analyzed and the two proteins were over-expressed, purified, and characterized.
\end{abstract}

Results: The results showed that exon-intron structures of AlaDC and SDC were quite similar and the protein sequences, encoded by the two genes, shared a high similarity of $85.1 \%$, revealing that new gene AlaDC originated from SDC by gene duplication. CSAlaDC and CSSDC catalyzed the decarboxylation of alanine and serine, respectively. CsAlaDC and CsSDC exhibited the optimal activities at $45^{\circ} \mathrm{C}(\mathrm{pH} 8.0)$ and $40^{\circ} \mathrm{C}(\mathrm{pH} 7.0)$, respectively. CsAlaDC was stable under $30^{\circ} \mathrm{C}(\mathrm{pH} 7.0)$ and CsSDC was stable under $40^{\circ} \mathrm{C}(\mathrm{pH} 6.0-8.0)$. The activities of the two enzymes were greatly enhanced by the presence of pyridoxal-5'-phosphate. The specific activity of CsSDC $(30,488$ IU/mg) was 8.8-fold higher than that of CsAlaDC (3467 IU/mg).

Conclusions: Comparing to CSAlaDC, its ancestral enzyme CSSDC exhibited a higher specific activity and a better thermal and pH stability, indicating that CSSDC acquired the optimized function after a longer evolutionary period. The biochemical properties of CSAlaDC might offer reference for theanine industrial production.

Keywords: Alanine decarboxylase (AlaDC), Serine decarboxylase (SDC), Camellia sinensis, Biochemical properties

\section{Background}

Tea is one of the most widely consumed beverages in the world. The popularity of tea could be attributed to its unique favor and health benefits $[1,2]$, which is provided by the special metabolites produced by tea plants

\footnotetext{
*Correspondence: nidj@mail.hzau.edu.cn; chenghao@tricaas.com

${ }^{\dagger}$ Peixian Bai and Liyuan Wang contributed equally to this work.

${ }^{2}$ College of Horticulture and Forestry Sciences, Huazhong Agricultural University, Wuhan 430070, Hubei, China

'National Center for Tea Improvement, Tea Research Institute Chinese Academy of Agricultural Sciences (TRICAAS), 9 Meiling South Road, Hangzhou 310008, Zhejiang, China
}

(Camellia sinensis) $[3,4]$. Theanine ( $\gamma$-glutamylethylamine), one of the specific metabolites in tea plants, is a key chemical component affecting green tea quality [46]. It is the most abundant non-protein amino acid in tea and accounts for more than $50 \%$ of the total free amino acids in tea plants [7]. Theanine plays important roles in nitrogen metabolism, especially in nitrogen storage [8] and ammonia detoxification [9]. Theanine also plays a crucial role in health promotion in humans, including improving memory [3], promoting concentration and relaxation, and reducing blood-pressure and mental

(c) The Author(s). 2021 Open Access This article is licensed under a Creative Commons Attribution 4.0 International License, which permits use, sharing, adaptation, distribution and reproduction in any medium or format, as long as you give appropriate credit to the original author(s) and the source, provide a link to the Creative Commons licence, and indicate if changes were made. The images or other third party material in this article are included in the article's Creative Commons licence, unless indicated otherwise in a credit line to the material. If material is not included in the article's Creative Commons licence and your intended use is not permitted by statutory regulation or exceeds the permitted use, you will need to obtain permission directly from the copyright holder. To view a copy of this licence, visit http://creativecommons.org/licenses/by/4.0/ The Creative Commons Public Domain Dedication waiver (http://creativecommons.org/publicdomain/zero/1.0/) applies to the data made available in this article, unless otherwise stated in a credit line to the data. 
stress [10]. Thus, theanine has been industrially produced and commercially developed as an additive used for food and beverages.

Theanine is synthesized from glutamate (Glu) and ethylamine catalyzed by theanine synthetase (TS) mainly in the roots of tea plants [11-14]. Ethylamine is derived mainly from the alanine decarboxylation catalyzed by alanine decarboxylase (AlaDC) [12, 14-16]. A great amount of theanine is accumulated in $C$. sinensis, but little or no theanine in other species $[17,18]$. A previous study revealed that the differential accumulation of theanine between $C$. sinensis and other species could be attributed to the availability of ethylamine [18], indicating that CsAlaDC was a crucial enzyme in theanine biosynthesis pathway. Up to now, the new gene AlaDC has been found and reported only in C. sinensis [16] but not in any other species. Based on the consistency of the distribution of theanine and new gene AlaDC among species, it seemed that the differential accumulation of theanine might be attributed to the origination of AlaDC.

Serine decarboxylase (SDC), belonging to the pyridoxal-5'-phosphate-dependent decarboxylase (PLP$\mathrm{deC}$ ) super family, has been found to be the protein most closely related to CsAlaDC [16]. Previous studies suggested that AlaDC [16] and SDC [19] catalyzed the decarboxylation of alanine (Ala) and serine (Ser), respectively. Ala is similar to Ser in the chemical structure with the side chain of Ala being a methyl $\left(-\mathrm{CH}_{3}\right)$ and that of Ser being a hydroxymethyl $\left(-\mathrm{CH}_{2} \mathrm{OH}\right)$. Based on the high similarity of the two enzymes in the protein sequence and catalytic activity, we speculated that the new gene AlaDC might originate from $S D C$.

It has been reported that the crude enzyme extracted from tea seedlings had the AlaDC activity [15], however, the biochemical properties of the pure enzyme CsAlaDC have not been characterized due to the lack of AlaDC gene sequence information. The $S D C$ gene in tea plants has not been identified previously. To determine the biochemical properties of the new enzyme CsAlaDC and its putative ancestral enzyme CsSDC, the coding sequences of the two proteins were inserted into expression vector pET-32a $(+)$, over-expressed in Escherichia coli BL21 (DE3), purified, and characterized.

\section{Results and discussion}

\section{New gene AlaDC originated from $S D C$ by gene} duplication

New genes were defined as those that are present in all members of a monophyletic group but absent from all outgroup species [20]. Our previous research has shown that AlaDC was a novel enzyme and SDC was the protein most closely related to AlaDC [16]. In this study, a BLAST search result showed that AlaDC gene was only found in tea plants, while the homologous genes of $S D C$ were widely distributed in monocots and dicots (Fig. 1). Therefore, AlaDC might be a new gene originated from $S D C$.

The $S D C$ gene was amplified from the cDNA of $C$. sinensis cv. longjing 43. DNA sequencing results revealed that this gene was a possible CsSDC product of 1455 bp encoding a protein with 484 aa. Pairwise alignment of the two proteins showed that the amino acid sequence of CsSDC shared $74.0 \%$ identity and $85.1 \%$ similarity to that CsAlaDC (Fig. 2b). The exon-intron structures of CsAlaDC and CsSDC were deduced from comparisons of tea genomic sequence with the cDNA sequences of the two genes. Results suggested that the exon-intron structures of the two genes are also similar. The CsAlaDC gene, consisting of six exons, is located around 62884956-62891561 bp of chromosome 1, while the CSSDC gene, consisting of five exons, is located around 62799219-62888308 bp of chromosome 7 (Fig. 2a). The length of the last four exons of CsSDC are exactly same as that of CsAlaDC. However, the first exon of $C s S D C$ seemed split into two exons (the first two exons of CsAlaDC) in CsAlaDC during evolution. The similarity of the two genes in exon-intron structure and coding sequence revealed that the new gene AlaDC originated from $S D C$ by gene duplication.

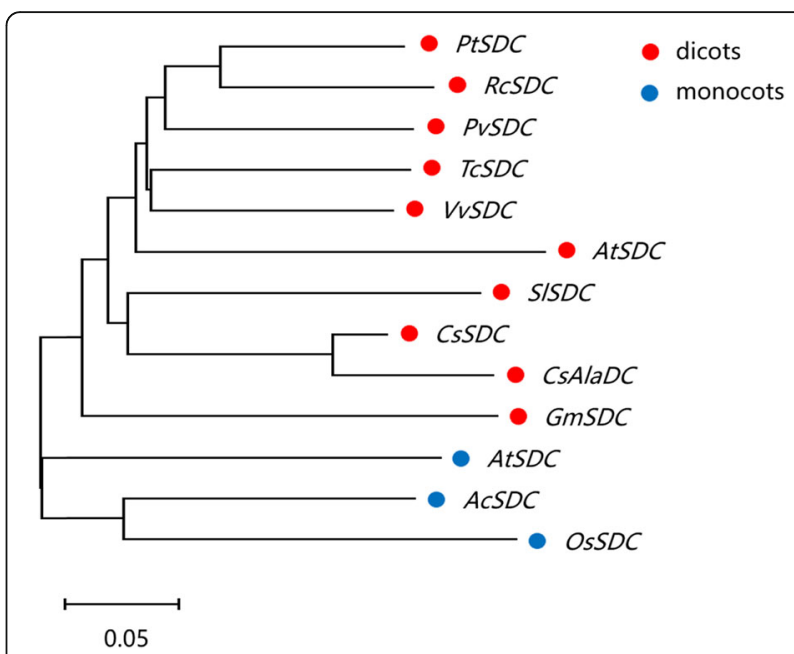

Fig. 1 Minimum-Evolution phylogenetic analysis of $A / a D C$ and SDC coding sequences from plants. The GenBank accession numbers of AlaDC and SDC genes used to build the phylogenetic tree are as follows: PtSDC (Populus trichocarpa SDC, XM_002306654.3); RCSDC (Ricinus communis SDC, XM_002532971.3); PvSDC (Pistacia vera SDC, XM_031428811.1); TCSDC (Theobroma cacao SDC, XM_007019401.2); VvSDC, (Vitis vinifera SDC, XM_002266362.4); AtSDC (Arabidopsis thaliana SDC, NM_03496.3); SISDC (Solanum lycopersicum SDC, XM_004237726.4); CsAlaDC (Camellia sinensis AlaDC, MN241445.1); GmSDC (Glycine max SDC, XM_003547539.3); AmtSDC (Amborella trichopoda SDC, XM_006854458.3); ACSDC (Ananas comosus SDC, XM_020256259.1); OsSDC (Oryza sativa SDC, XM_015771197.1) 


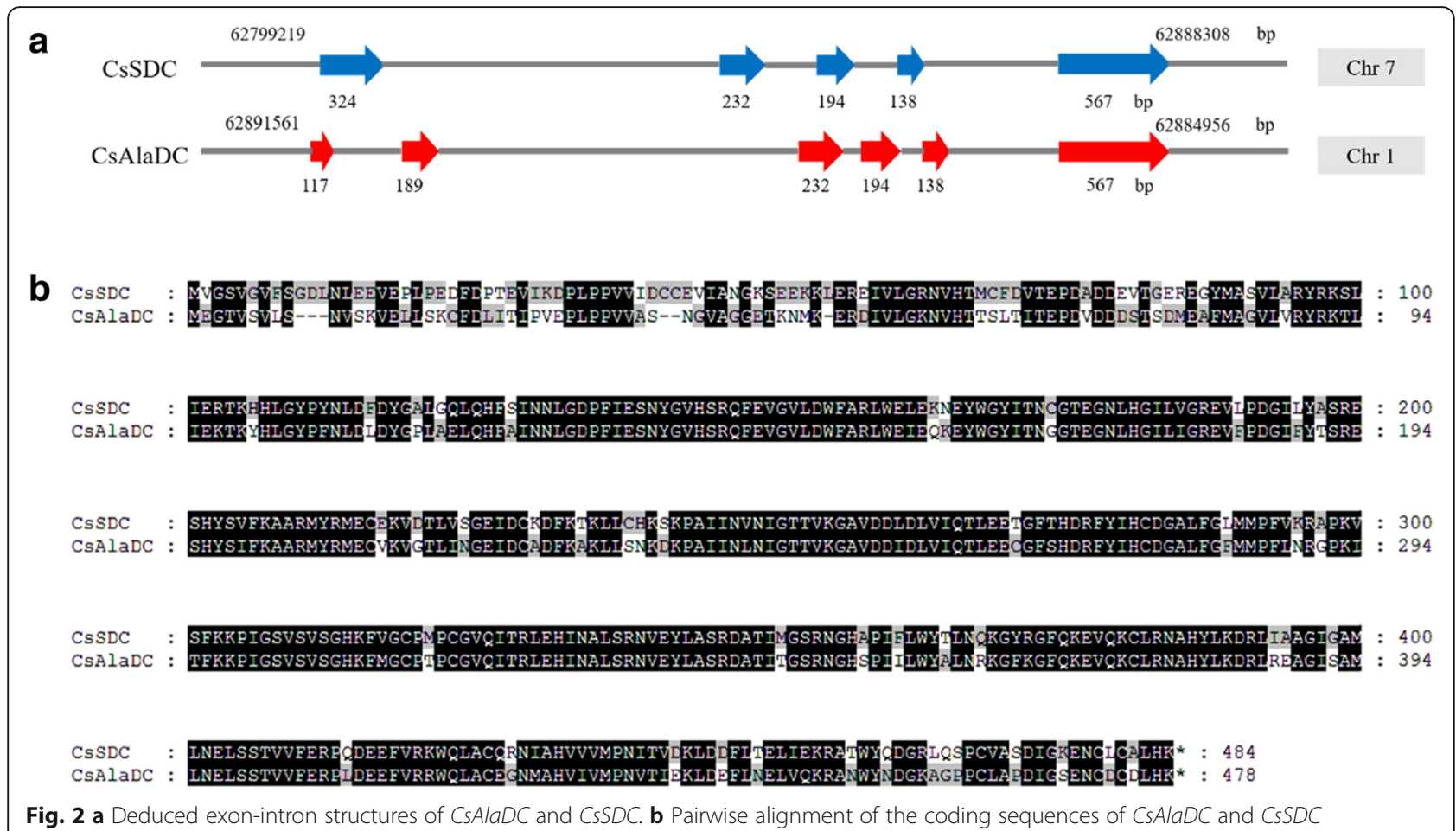

\section{Overexpression and purification of CsAlaDC and CsSDC}

The genes CsAlaDC and CsSDC were inserted into the pET-32a (+) expression vector with a His $_{6}$-tag at $\mathrm{N}$ terminal. Two proteins were over-expressed in $E$. coli BL21 (DE3) cells and purified using $\mathrm{Ni}^{+}$affinity chromatography. The purified proteins were identified by using 12\% SDS-PAGE and western blot analysis (Fig. 3A and 3B). The molecular mass of CsSDC was estimated approximately as $75 \mathrm{kDa}$, which is slightly larger than that of CsAlaDC. The activities of the two enzymes catalyzing the decarboxylation of Ala (for CsAlaDC) and Ser (for CsSDC) were detected as indicators of enzyme purity (Fig. 3D). The specific activities of the crude proteins were $936 \mathrm{IU} / \mathrm{mg}$ (CsAlaDC) and $5980 \mathrm{IU} / \mathrm{mg}$ (CsSDC), respectively. After purification, the specific activities of the two enzymes increased to 3.1-fold (CsAlaDC) and 5.1-fold (CsSDC), respectively (shown in Table 1).

\section{Effect of PLP on enzyme activity}

Previous studies reported that PLP was a cofactor of the PLP-deC, thus the effects of PLP on the enzymatic activities of CsAlaDC and CsSDC were examined. As shown in Fig. 3C, the activities of the two enzymes were significantly increased at the presence of PLP $(0.1 \mathrm{mM})$. When there was no PLP in the reaction mixture, the activity of CsAlaDC was low and CsSDC was almost inactive. When PLP $(0.1 \mathrm{mM})$ was added to the reaction mixture, the activity of CsAlaDC increased 7.37 folds and CsSDC was rapidly activated. This result indicated that the activities of CsAlaDC and CsSDC are significantly dependent on the presence of PLP.

The increase in enzyme activities at the presence of PLP was also observed in other PLP-dependent amino acid decarboxylases (AADs). For example, in PLPdeficient mixture, the activity of SDC in Arabidopsis thaliana was low, whereas after the addition of PLP, the enzyme activity increased more than 30 folds [19]. Human histidine decarboxylase (HDC) in PLP-deficient mixture showed only $30 \%$ of normal activity (in PLPpresent mixture) and the addition of PLP restored the activity to normal level [21]. The activities of arginine decarboxylase (ADC) [22] and tyrosine decarboxylase (TYDC) were also significantly increased when PLP was added to the reaction mixture [23].

A previous study showed that the AlaDC activity of crude protein extracted from tea seedlings was not activated by PLP [15]. That was inconsistent with the results obtained in the present study and with the properties of other AADs reported previously. Previous research revealed that, at the presence of PLP, the PLP-dependent decarboxylase shifted from an unstable open conformation to a stable closed conformation by binding to PLP $[24,25]$. The AlaDC activity measured in the previous study was the activity of crude protein extracted from tea seedlings, and the protein might had already bound to PLP required for the decarboxylation reaction before it was extracted. Thus, even the addition of PLP to the reaction system had little effect on enzyme activity. 


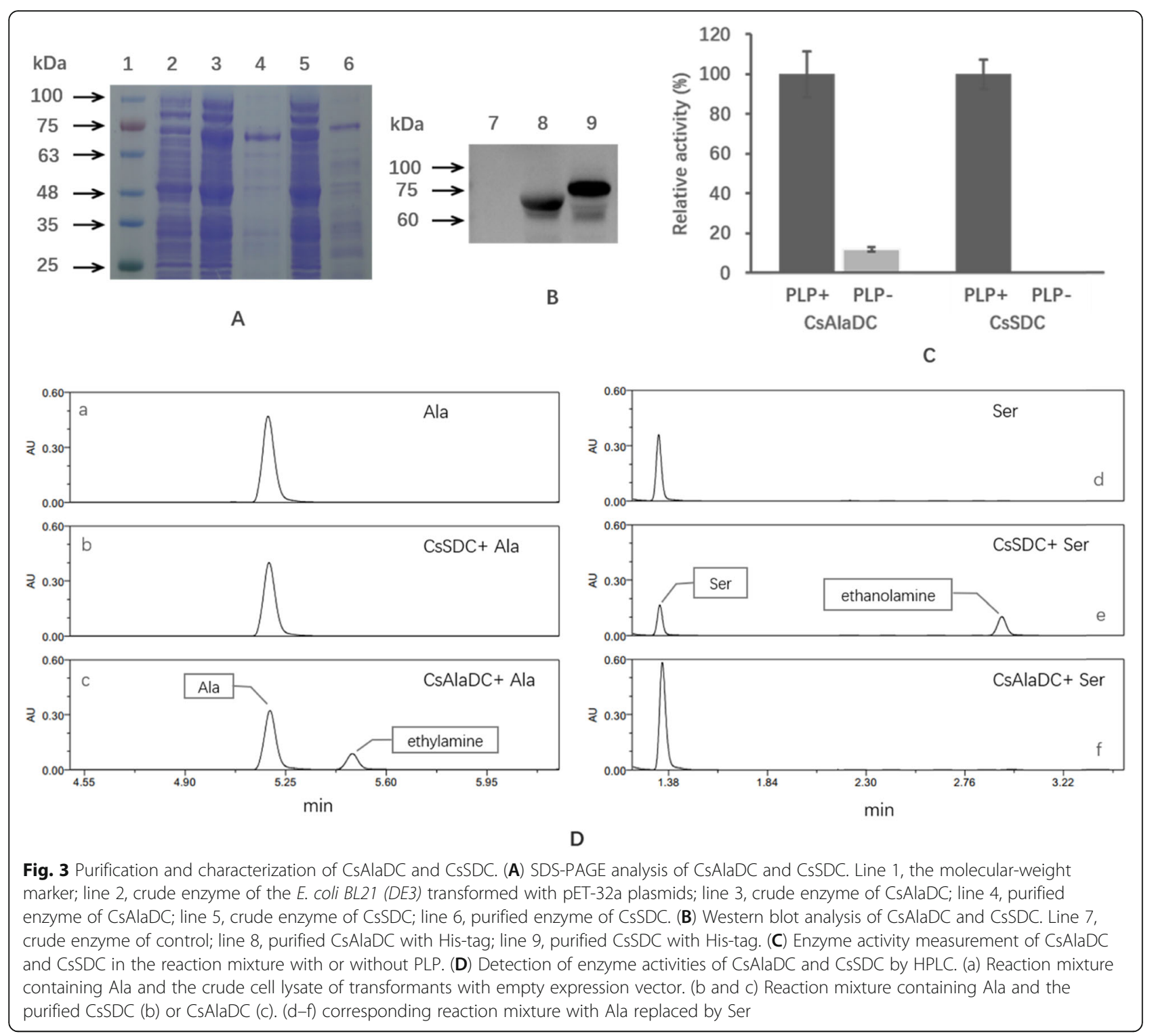

\section{Substrate specificity}

To investigate the substrate specificity of CsAlaDC and CsSDC, the activities of the two enzymes were detected with various substrates, including Ala, Ser, histidine, glutamate, arginine, tyrosine, and tryptophan. The corresponding amines produced in the reaction mixture were detected by UPLC. The results showed that CsAlaDC could only catalyze the decarboxylation of Ala, but not Ser or other amino acids. CsSDC could only catalyze the decarboxylation reaction of Ser, but not Ala or other amino acids (as shown in Fig. 3D). Therefore, CsAlaDC and CsSDC had completely different biochemical functions and were responsible for catalyzing the decarboxylation of Ala and Ser, respectively.

Table 1 Purification of recombinant protein CsAlaDC and CsSDC

\begin{tabular}{lllllll}
\hline Enzyme & Purification step & Total protein $(\mathbf{m g})$ & Total activity (IU) & Specific activity (IU/mg) & Yield (\%) & Purification fold \\
\hline CSAlaDC & Crude protein & 142.7 & 133,491 & 936 & 35.5 & 3.7 \\
& Purified protein & 13.7 & 47,383 & 3467 & & \\
CSSDC & Crude protein & 130.6 & 780,720 & 5980 & 5.1 \\
& Purified protein & 11.6 & 352,756 & 30,488 & & \\
\hline
\end{tabular}




\section{Optimal pH for enzyme activity and stability}

The optimal $\mathrm{pH}$ of CsAlaDC and CsSDC was found to be 8.0 and 7.0, respectively (Fig. $4 \mathrm{a}$ and $4 \mathrm{c}$ ). CsAlaDC maintained high enzyme activity only in a very narrow $\mathrm{pH}$ range (Fig. 4a). When the $\mathrm{pH}$ value dropped from 8.0 to 7.0 , the enzyme activity of CsAlaDC decreased to $57.8 \%$ of its maximum activity, while at $\mathrm{pH} 6.5$ and 8.5 , its activity decreased to 25.4 and $23.7 \%$, respectively. Whereas, CsSDC maintained high enzyme activity (> 85\%) over a wide $\mathrm{pH}$ range ( $\mathrm{pH} 6.5-8.0)$, indicating that CsSDC was more adaptable to environment changes than CsAlaDC. A previous study suggested that the maximum AlaDC activity of the crude protein extracted from tea seedlings was detected at pH 6.25 [15], which was different from the results obtained in the present study. This might be attributed to the fact that the crude protein extracted from tea seedlings might contain other enzymes or components, resulting in differences in the measured optimum $\mathrm{pH}$ of the crude enzyme and pure enzyme CsAlaDC.

The optimal pH for other AADs was between 3.8 and 8.5. Some enzymes had an optimum $\mathrm{pH}$ similar to that of CsAlaDC and CsSDC, such as AtSDC [19], ADC (pH 6.5-8.5) $[22,26,27]$ and tyrosine decarboxylase (TDC) (pH 7.0-8.5) [23, 28]. Some decarboxylases showed the best enzymatic activity under weakly acidic conditions, such as HDC (pH 4.4-7.0) [29], while others have a wide $\mathrm{pH}$ range, such as glutamate decarboxylase (GAD) $(\mathrm{pH}$ 3.8-8.0) [30-33].

To investigate the stability of CsAlaDC and CsSDC under different $\mathrm{pH}$ conditions, the two enzymes were treated in $\mathrm{pH} 6.0-9.0$ buffer $\left(4^{\circ} \mathrm{C}\right)$ for $1,6,12$ and $24 \mathrm{~h}$, respectively, and the residual enzyme activities were measured. The results showed that the two enzymes were stable in $\mathrm{pH} 6.0-8.0$, and the enzyme activities decreased rapidly when the $\mathrm{pH}$ value reached 9.0 (Fig. $4 \mathrm{~b}$ and $4 \mathrm{~d}$ ). Surprisingly, the enzymatic activity of CsAlaDC and CsSDC significantly increased within $6 \mathrm{~h}$ under suitable $\mathrm{pH}$ conditions ( $\mathrm{pH}$ 6.0-8.0). After 6-h incubation at $\mathrm{pH} 7.0$, the enzyme activities of CsAlaDC and CsSDC increased to 3.1 folds and 1.5 folds, respectively. This might be due to the pre-addition of coenzyme PLP to buffers of different pHs, where PLP bind to the decarboxylases during incubations, resulting in higher enzyme activities after treatments. Although CsAlaDC showed the best enzyme activity at $\mathrm{pH} 8.0$, the enzyme was more stable at $\mathrm{pH}$ 7.0. Therefore, the reaction conditions at $\mathrm{pH} 7.0$ would be favorable for the industrial production of theanine. The AADs with similar pH stability to CsAlaDC and CsSDC were ADC (pH 7.0-7.5) [22] and TDC [34] (pH 7.4). Whereas HDC ( $\mathrm{pH} 4.5)$ [29] and GAD ( $\mathrm{pH}$ 5.0-7.0) [32, 33] were more stable in acidic environments. This study revealed that CsAlaDC was stable at $\mathrm{pH} 7.0$ and CsSDC was stable at $\mathrm{pH} 6.0-8.0$, and the $\mathrm{pH}$ stability of the two enzymes might offer reference for theanine industrial production and reflect their adaptation to intracellular $\mathrm{pH}$ of $C$. sinensis.

\section{Optimal temperature for enzyme activity and stability}

The activities of CsAlaDC and CsSDC increased with increasing temperature below $40^{\circ} \mathrm{C}$. The two enzymes reached their maximum activities at $45^{\circ} \mathrm{C}$ (for CsAlaDC) and $40^{\circ} \mathrm{C}$ (for CsSDC), respectively (Fig. $4 \mathrm{e}$ and $4 \mathrm{~g}$ ). While at $50{ }^{\circ} \mathrm{C}$, the activities of the two enzymes decreased rapidly to $42.6 \%$ (for CsAlaDC) and $36.2 \%$ (for CsSDC) of their maximum activities, respectively.

The optimum temperature for the other AADs was between $30^{\circ} \mathrm{C}$ and $70{ }^{\circ} \mathrm{C}$. Each decarboxylase had a different optimum temperature depending on the species of origin. For example, GADs in Lactobacillus brevis and Escherichia coli had lower optimum temperature of $30^{\circ} \mathrm{C}$ and $37^{\circ} \mathrm{C}$, respectively. The optimal temperature of GADs in Enterrococcus raffinosus, Lactobacillus paracasei and Streptococcus salivarius, were between $45^{\circ} \mathrm{C}$ and $55^{\circ} \mathrm{C}$, while in Aspergillus Oryzae was up to $60^{\circ} \mathrm{C}$ [30]. Even for GADs in different strains of Lacto bacillus, the optimal reaction temperatures varied $\left(30-55^{\circ} \mathrm{C}\right)$ [31]. Similarly, the optimal reaction temperatures of ADCs from different strains were varied. The optimal temperatures of ADCs in Bacillus subtilis and Yersinia pestis was $37^{\circ} \mathrm{C}$, in E. coli was $50^{\circ} \mathrm{C}$, in Clostridium difficile was $60^{\circ} \mathrm{C}$ and in Chloroflexus aurantiacus and Slufolobus solfataricus was up to $70^{\circ} \mathrm{C}$ [22].

The thermal stability of CsAlaDC and CsSDC at $20^{\circ} \mathrm{C}$ to $50{ }^{\circ} \mathrm{C}$ was investigated. The results showed that CsSDC was more thermally stable than CsAlaDC (Fig. $4 \mathrm{f}$ and $4 \mathrm{~h}$ ). There was no detectable activity of both enzymes after 1-h incubation at $50{ }^{\circ} \mathrm{C}$. After 1-h incubation at $40^{\circ} \mathrm{C}$, CsAlaDC lost almost all of its activity, while CsSDC still maintained $64.4 \%$ of its activity. After 1 -h incubation at $30^{\circ} \mathrm{C}$, the residual enzyme activity of CsAlaDC was $73.3 \%$, and that of CsSDC was $96.8 \%$. After 1 $\mathrm{h}$ incubation at $20^{\circ} \mathrm{C}$, both enzymes maintained almost full enzyme activity. After 12 -h incubation at $30^{\circ} \mathrm{C}$, CsAlaDC lost all its enzyme activity, and CsSDC maintained $23.0 \%$. After $24-\mathrm{h}$ incubation at $20^{\circ} \mathrm{C}$, the residual activity of both enzymes was $25.4 \%$ (CsAlaDC) and $29.8 \%$ (CsSDC), respectively.

Other AADs seemed to be more thermally stable than CsSDC and CsAlaDC. For instance, after 1-h incubation at $40{ }^{\circ} \mathrm{C}$, ADC from E. coli could maintain $78.6 \%$ of its initial activity, and TYDC from Lactobacillus subtilis could maintain more than 90\% [34]. ErGAD maintained more than $85 \%$ of its initial activity after 5 -h incubation at $50{ }^{\circ} \mathrm{C}$ [30], and GAD from Bacillus megaterium maintained more than $75 \%$ activity after 6 -h incubation at $40{ }^{\circ} \mathrm{C}[32]$. 


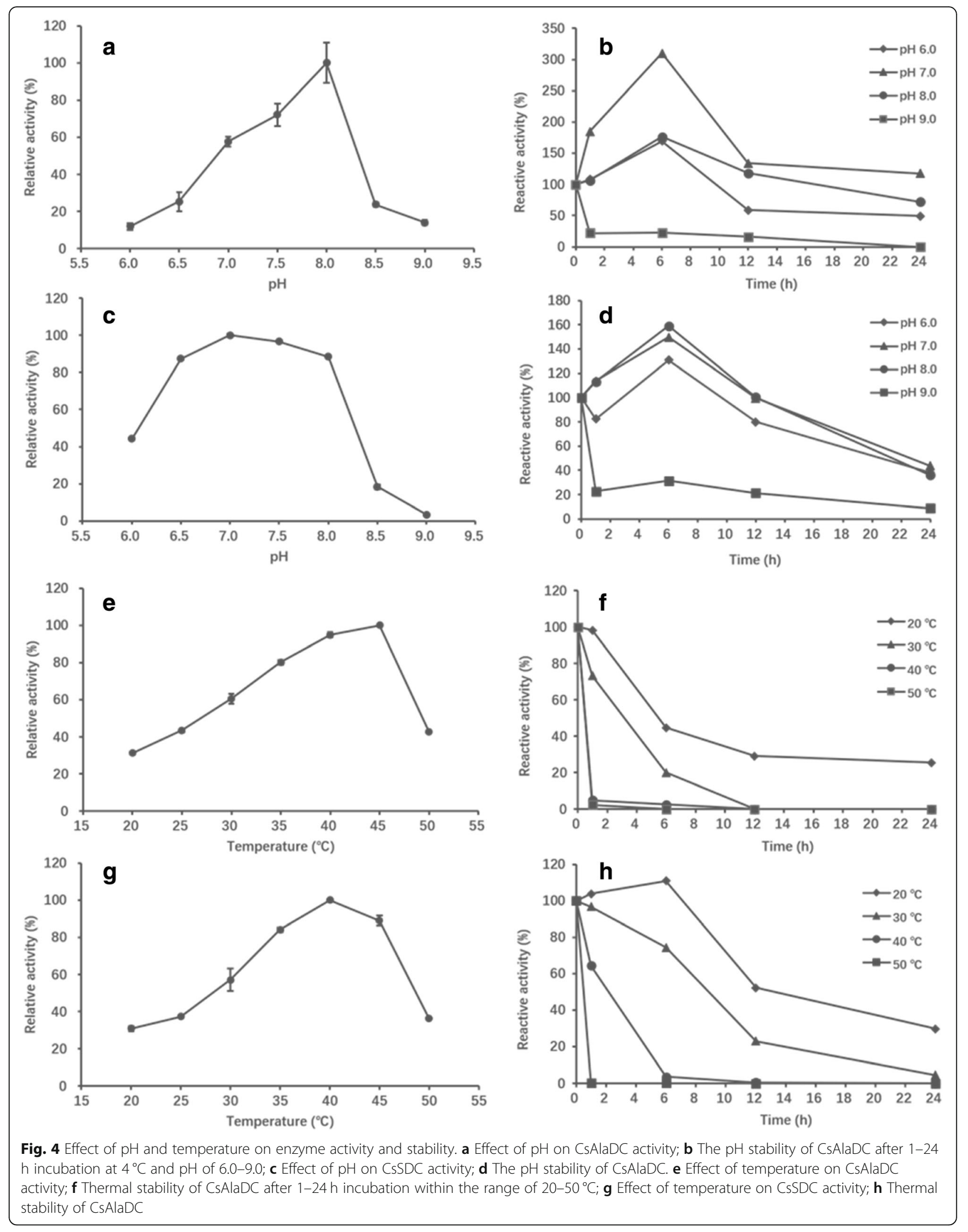


The maximal activity of CsAlaDC and CsSDC was detected at $45{ }^{\circ} \mathrm{C}$ and $40{ }^{\circ} \mathrm{C}$, respectively (Fig. $4 \mathrm{e}$ and $4 \mathrm{~g}$ ). However, the two enzymes showed poor stability at temperature above $40{ }^{\circ} \mathrm{C}$. Since temperature up to $40^{\circ} \mathrm{C}$ led to the decrease in enzyme stability, $30-35^{\circ} \mathrm{C}$ was recommended as a suitable condition in industrial application.

\section{Kinetic parameters}

The kinetic parameters of CsAlaDC and CsSDC were determined by Lineweaver-Burk Plots (Fig. $5 \mathrm{~b}$ and $5 \mathrm{~d}$ ) using corresponding substrate (Fig. $5 \mathrm{a}$ and $\mathrm{c}$ ). The $\mathrm{V}_{\max }$ of CsSDC (30.49 $\left.\mathrm{mmol} \cdot \mathrm{min}^{-1} \mathrm{mg}^{-1}\right)$ was 8.8-fold higher than that of CsAlaDC $\left(3.47 \mathrm{mmol} \cdot \mathrm{min}^{-1} \mathrm{mg}^{-1}\right.$ ) (shown in Table 2), indicating that the new enzyme CsAlaDC had a much lower catalytic efficiency than its ancestral enzyme CsSDC. The $K_{m}$ value of CsAlaDC $(33.25 \mathrm{mM})$ was much higher than that of CsSDC $(9.42 \mathrm{mM})$, which was close to the $K_{m}$ value of AtSDC $(10 \mathrm{mM})$ reported in the previous study [19]. This result suggested that the substrate affinity of CsAlaDC was lower than that of CsSDC and AtSDC. Among other AADs, except GADs (0.045-22.9 mM) [30-33], most AADs were reported to have a $\mathrm{K}_{\mathrm{m}}$ value lower than that of CsAlaDC $(33.25 \mathrm{mM})$ and CsSDC (9.42 mM), including HDC $(0.2-0.8 \mathrm{mM})$
Table 2 Kinetic parameters of CSAlaDC and CsSDC

\begin{tabular}{llll}
\hline Enzyme & Substrate & $\mathbf{K}_{\mathbf{m}}(\mathbf{m M})$ & $\mathbf{V}_{\mathbf{m a x}}\left(\mathbf{m m o l} \cdot \mathbf{m i n}^{\mathbf{- 1}} \mathbf{~ m}^{\mathbf{- 1}}\right)$ \\
\hline CsAlaDC & alanine & 33.25 & 3.47 \\
CsSDC & serine & 9.42 & 30.49 \\
\hline
\end{tabular}

[29, 35], ADC $(0.03-5.6 \mathrm{mM})[22,26,27]$ and TDC $(0.25-0.6 \mathrm{mM})[23,28,34]$.

A recent study also measured the activity of CsAlaDC expressed by prokaryotic system, and the results suggested that the protein had no AlaDC activity [36]. There are four possible reasons for these results. Firstly, the amino acid sequence of CsAlaDC used in that study was not identical to the sequence used in the present and in our previous study. The coding sequence of CsAlaDC gene was submitted to GenBank (accession number: MN241445.1). Secondly, as reported in the present study, the enzymatic activity of CsAlaDC was significantly dependent on the presence of PLP, which was absent from the reaction system in that study. Thirdly, the AlaDC activity was assayed by measuring the substrate (Ala) consumption in that study. That method might not be accurate enough due to the relatively low activity of new enzyme CsAlaDC. Finally, compared with the mature enzyme CsSDC, the new enzyme CsAlaDC had lower enzymatic activity, was unstable and easily

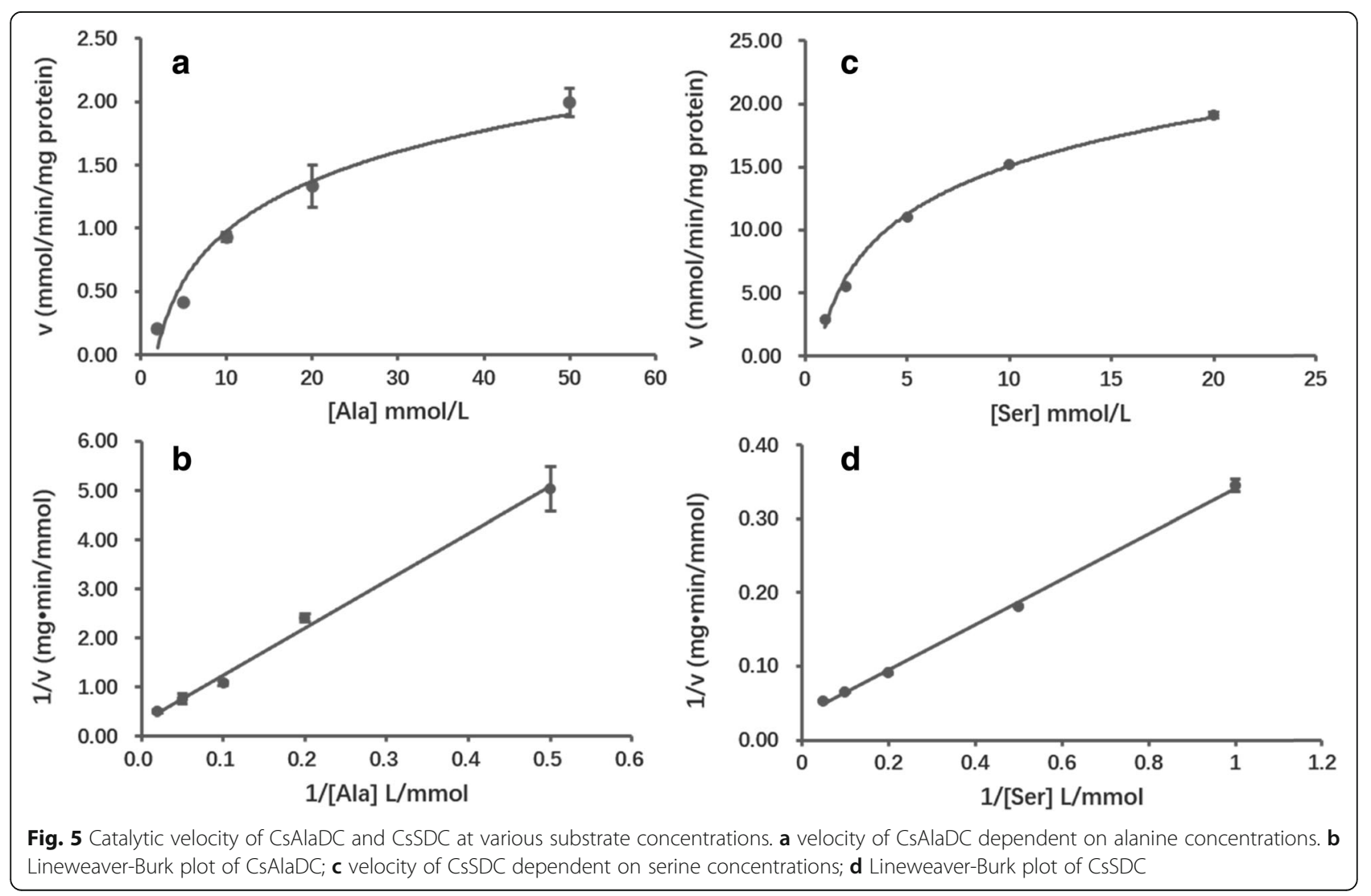


deactivated, therefore, before using CsAlaDC for theanine production, the expression and reaction conditions of the enzyme need to be optimized, as reported in this study.

\section{Conclusion}

In conclusion, an SDC from C. sinensis was identified as the ancestral enzyme of AlaDC. The high similarity of CsAlaDC and CsSDC in gene structures and their encoded protein sequences revealed that the new gene AlaDC originated from $S D C$ by gene duplication. CsSDC and CsAlaDC are enzymes that specifically catalyze the decarboxylation of Ser and Ala, respectively. The activities of the two enzymes were greatly enhanced by the presence of pyridoxal-5' -phosphate. Comparing to CsAlaDC, its ancestral enzyme CsSDC exhibited a higher specific activity and a better thermal and $\mathrm{pH}$ stability. The specific activity of CsSDC (30,488 IU/mg) was 8.8 fold higher than that of CsAlaDC (3467 IU/mg). CsAlaDC was stable under $30^{\circ} \mathrm{C}(\mathrm{pH} 7.0)$ and $\mathrm{CsSDC}$ was stable under $40^{\circ} \mathrm{C}$ (p H 6.0-8.0). This study characterized the biochemical properties of CsAlaDC and its ancestral enzyme CsSDC, further efforts should be made to find the active sites or the key residues affecting the substrate specificity of the two enzymes.

\section{Methods}

\section{Sequence analysis of CsAlaDC and CsSDC}

The CsAlaDC gene used was from the recombinant plasmid previously conserved in our laboratory. The gene sequence of $C S S D C$ was found from the transcriptome of $C$. sinensis and the gene was isolated from the cDNA of $C$. sinensis cv. longjing 43. The PCR products were confirmed by $1.2 \%$ agarose gel electrophoresis and DNA sequencing. Homologous genes from different plant species were obtained from non-redundant sequence database of transcripts. The phylogenetic tree of these AADs was constructed using the MinimumEvolution method with MEGA X. To determine the exon-intron structures of CsAlaDC and CsSDC, the cDNA sequences of those two genes were aligned to the genomic sequence of C. sinensis [37]. Alignment of the protein sequences of CsAlaDC and CsSDC was conducted by MEGA X.

\section{Overexpression and purification of recombinant protein}

The genes CsAlaDC and CsSDC were inserted into expression vector $\mathrm{pET}-32 \mathrm{a}(+)$ with a $\mathrm{His}_{6}$-tag at $\mathrm{N}$ terminal and the recombinant plasmids were transferred into E. coli BL21 (DE3) (Shanghai Weidi biotechnology, China), grown in LB medium containing $100 \mu \mathrm{g} / \mathrm{mL}$ ampicillin at $37^{\circ} \mathrm{C}$. When the optical density (OD) at $600 \mathrm{~nm}$ reached 0.4-0.6, IPTG (iso-propyl $\beta$-D-1-thiogalactopyranoside) (Solarbio, China) was added with a final concentration of $0.1 \mathrm{mM}$, and the cells were cultured at $16^{\circ} \mathrm{C}$ for $16 \mathrm{~h}$, harvested by centrifugation at $4{ }^{\circ} \mathrm{C}$ and $4000 \mathrm{rpm}$ for $30 \mathrm{~min}$, washed with distilled water, and resuspended in phosphate-buffered saline (PBS, pH 7.4) (Solarbio, China). The recombinant proteins were extracted through cell ultrasonication disruption $\left(200 \mathrm{~W}, 5 \mathrm{~s}, 5 \mathrm{~s}, 20 \mathrm{~min}\right.$ ) and centrifugation (at $4{ }^{\circ} \mathrm{C}$ and $12,000 \mathrm{rpm}, 30 \mathrm{~min}$ ). The supernatants were purified with a Ni-Agarose resin column (CWBIO, China). The purified proteins were detected by $12.5 \%$ sodium dodecyl sulfate-polyacrylamide gel electrophoresis (SDS-PAGE) (Bio-Rad, USA). The presence of His-tagged CsAlaDC and CsSDC were verified by western blot analysis using an His-tag monoclonal antibody (Proteintech, USA) and an anti-mouse $\lg G$ as the primary and secondary antibodies. Protein concentration was measured by Bradford method with bovine serum albumin (BSA) as a standard.

\section{Enzyme activity assays}

Decarboxylase activity was measured with detecting products (ethylamine or ethanolamine) in Waters Acquit ultraperformance liquid chromatography (UPLC) system. The $100 \mu \mathrm{L}$ reaction mixture, containing $20 \mathrm{mM}$ substrate (Ala or Ser), $100 \mathrm{mM}$ potassium phosphate 0.1 $\mathrm{mM}$ pyridoxal-5' -phosphate (PLP), $5 \mathrm{mM} \mathrm{L}$-dithiothreitol, $1 \mathrm{mM} \mathrm{K} \mathrm{K}_{2}$ EDTA (Sangon Biotech, China), 10\% glycerol, and $20 \mu \mathrm{L}$ purified enzyme ( $12 \mu \mathrm{g}$ protein), was prepared and incubated at standard conditions $\left(45^{\circ} \mathrm{C}\right.$ and $\mathrm{pH} 8.0$ for CsAlaDC, $40^{\circ} \mathrm{C}$ and $\mathrm{pH} 7.0$ for CsSDC) for $15 \mathrm{~min}$. Then, the reaction was stopped with $20 \mu \mathrm{L}$ of $10 \%$ trichloroacetic acid. After derivatization with AccQ.Tag reagents (Waters, USA), the reaction products in the mixture were analyzed with UPLC. All enzymatic assays were performed in triplicate.

\section{Effect of PLP on enzyme activity}

To investigate the effect of PLP on enzyme activity, the enzyme activity of the reaction mixture was measured at standard conditions with $20 \mathrm{mM}$ substrate at the presence or absence of $0.1 \mathrm{mM}$ PLP. The enzyme activity of reaction mixture containing PLP was taken as $100 \%$.

\section{Substrate specificity of CsAlaDC and CsSDC}

The substrate specificity was measured at standard conditions with $5 \mathrm{mM}$ substrates including serine, alanine, histidine, arginine, glutamate, tyrosine and tryptophan, respectively.

\section{Optimal $\mathrm{pH}$ and $\mathrm{pH}$ stability}

The optimal pHs of purified enzymes were determined by using reaction mixture with $\mathrm{pH}$ ranging from 6.0 to 9.0. To examine $\mathrm{pH}$ stability of the enzymes, the residual activities were measured at standard conditions after pre-incubation at $\mathrm{pH}$ value range of $6.0-9.0$ for $1,6,12$ 
and $24 \mathrm{~h}$, respectively. The enzyme activity at optimal $\mathrm{pH}$ was taken as $100 \%$, and the percentage of the residual activities at different $\mathrm{pH}$ values against enzyme activity at optimal $\mathrm{pH}$ were calculated as relative activities.

\section{Optimal temperature and thermal stability}

The optimal temperatures of purified enzymes were determined by performing the reactions at temperature range from $20^{\circ} \mathrm{C}$ to $50^{\circ} \mathrm{C}$. To investigate thermal stability of the two enzymes, residual activities were measured at standard conditions after pre-incubation within temperature range of $20-50^{\circ} \mathrm{C}$ for $1,6,12$ and $24 \mathrm{~h}$, respectively. The enzyme activity at optimal temperature was taken as $100 \%$, and the percentage of the residual activities at different temperature values against the enzyme activity at optimal temperature were calculated as relative activities.

\section{Kinetic parameters}

Kinetic parameters of the two enzymes were measured at standard conditions by applying different concentrations of Ala and Ser in the reaction mixtures. The concentrations of Ala and Ser ranged from $1 \mathrm{mM}$ to100 $\mathrm{mM}$. According to Lineweaver-Burk plots, $\mathrm{K}_{\mathrm{m}}$ and $\mathrm{V}_{\max }$ values were calculated.

\section{Supplementary Information}

The online version contains supplementary material available at https://doi. org/10.1186/s12896-021-00674-x.

Additional file 1 .

\section{Abbreviations}

AAD: Amino acid decarboxylase; ADC: Arginine decarboxylase; Ala: Alanine; AlaDC: Alanine decarboxylase; BSA: Bovine serum albumin; GAD: Glutamate decarboxylase; Glu: Glutamate; HDC: Histidine decarboxylase; IPTG: Iso-propyl $\beta$-D-1-thiogalactopyranoside; OD: Optical density; PBS: Phosphate-buffered saline; PLP: Pyridoxal-5'-phosphate; PLP-deC: Pyridoxal-5'-phosphatedependent decarboxylase; SDC: Serine decarboxylase; SDS-PAGE: Sodium dodecyl sulfate-polyacrylamide gel electrophoresis; Ser: Serine; TDC: Tyrosine decarboxylase; TS: Theanine synthetase; TYDC: Tyrosine decarboxylase; UPLC: Ultraperformance liquid chromatography

\section{Acknowledgments}

This work was supported by the Central Public Interest Scientific Institution Basal Research Fund (1610212018004), Earmarked Fund for China Agriculture Research System (CARS-19) and the Major Science and Technology Special Project of Variety Breeding of Zhejiang Province (2016C02053-6).

\section{Supporting information}

The coding sequence of CSAlaDC gene is available in GenBank (accession number: MN241445.1) and the coding sequence of CSSDC is shown in S1 (PDF).

\section{Authors' contributions}

H.C. and D.N. conceived and designed the experiments; M.H. and L.R. contributed to UPLC analysis; P.B. and L.Wu performed the molecular experiment; L.Wang analyzed the data and prepared figures; P.B. and L.Wang wrote the manuscript draft; H.C., D.N. and K.W. edited and revised the manuscript. All authors read and approved the final manuscript.

\section{Availability of data and materials}

All data generated or analyzed during this study are included in this published article [and its supplementary information files].

\section{Competing interests}

The authors declare that they have no competing interest.

Received: 17 September 2020 Accepted: 10 December 2020

Published online: 01 March 2021

\section{References}

1. Saeed M, Naveed M, Arif M, Kakar MU, Manzoor R, El-Hack MEA, Alagawany M, Tiwari R, Khandia R, Munjal A, et al. Green tea (Camellia sinensis) and Ltheanine: medicinal values and beneficial applications in humans-a comprehensive review. Biomed Pharmacother. 2017;95:1260-75.

2. Yang Z, Baldermann S, Watanabe N. Recent studies of the volatile compounds in tea. Food Res Int. 2013;53(2):585-99.

3. Kim TI, Lee YK, Park SG, Choi IS, Ban JO, Park HK, Nam S-Y, Yun YW, Han SB, Oh KW, et al. L-Theanine, an amino acid in green tea, attenuates betaamyloid-induced cognitive dysfunction and neurotoxicity: reduction in oxidative damage and inactivation of ERK/p38 kinase and NF-kappa B pathways. Free Radic Biol Med. 2009;47(11):1601-10.

4. Wei K, Ruan L, Li H, Wu L, Wang L, Cheng H. Estimation of the effects of major chemical components on the taste quality of green tea. Int Food Res J. 2019:26(3):869-76.

5. Kaneko S, Kumazawa K, Masuda H, Henze A, Hofmann T. Molecular and sensory studies on the umami taste of Japanese green tea. J Agric Food Chem. 2006;54(7):2688-94.

6. Zhang J, Sun D, Su G, Zhao M. New insight into umami receptor, umami/ umami-enhancing peptides and their derivatives: a review. Trends Food Sci Technol. 2019:88:429-38.

7. Li F, Dong C, Yang T, Ma J, Zhang S, Wei C, Wan X, Zhang Z. Seasonal theanine accumulation and related gene expression in the roots and leaf buds of tea plants (Camellia Sinensis L.). Front Plant Sci. 2019;10:14.

8. Feldheim $\mathrm{W}$, Yongvanit $\mathrm{P}$, Cummings $\mathrm{PH}$. Investigation of the presence and significance of theanine in the tea plant. J Sci Food Agric. 1986; 37(6):527-34.

9. Ashihara H. Occurrence, biosynthesis and metabolism of theanine (gammaGlutamyl-L-ethylamide) in plants: a comprehensive review. Nat Prod Commun. 2015:10(5):803-10.

10. Unno K, Noda S, Kawasaki Y, Yamada H, Morita A, Iguchi K, Nakamura Y. Anti-stress effect of green tea with lowered caffeine on humans: a pilot study. Biol Pharm Bull. 2017:40(6):902-9.

11. Sasaoka K, Kito M. Synthesis of theanine by tea seedling homogenate. Agric Biol Chem. 1964;28(5):313-7.

12. Takeo T. I-alanine as a precursor of ethylamine in Camellia sinensis. Phytochemistry. 1974;13(8):1401-6.

13. Deng W, Ogita S, Ashihara H. Biosynthesis of theanine (gamma-ethylaminoL-glutamic acid) in seedlings of Camellia sinensis. Phytochem Lett. 2008;1(2): $115-9$.

14. Deng W, Ogita S, Ashihara H. Ethylamine content and theanine biosynthesis in different organs of Camellia sinensis seedlings. Zeitschrift Fur Naturforschung Section C-a J Biosci. 2009;64(5-6):387-90.

15. Takeo T. I-alanine decarboxylase in Camellia sinensis. Phytochemistry. 1978; 17(2):313-4.

16. Bai P, Wei K, Wang L, Zhang F, Ruan L, Li H, Wu L, Cheng H. Identification of a novel gene encoding the specialized alanine decarboxylase in tea (Camellia sinensis) plants. Molecules. 2019;24(3):15.

17. Deng W, Ogita S, Ashihara H. Distribution and biosynthesis of theanine in Theaceae plants. Plant Physiol Biochem. 2010;48(1):70-2.

18. Cheng S, Fu X, Wang X, Liao Y, Zeng L, Dong F, Yang Z. Studies on the biochemical formation pathway of the amino acid L-Theanine in tea (Camellia sinensis) and other plants. J Agric Food Chem. 2017;65(33):7210-6.

19. Rontein D, Nishida I, Tashiro G, Yoshioka K, Wu W, Voelker DR, Basset GJ, Hanson AD. Plants synthesize ethanolamine by direct decarboxylation of serine using a pyridoxal phosphate enzyme. J Biol Chem. 2001;276(38): 35523-9.

20. Long M, VanKuren NW, Chen S, Vibranovski MD. New gene evolution: little did we know. Annu Rev Genet. 2013;47:307-33. 
21. Yatsunami K, Tsuchikawa M, Kamada M, Hori K, Higuchi T. Comparative studies of human recombinant 74- and 54-kda L-Histidine decarboxylases. J Biol Chem. 1995;270(51):30813-7.

22. Sun $X$, Song W, Liu L. Enzymatic production of agmatine by recombinant arginine decarboxylase. J Mol Catalysis B-enzymatic. 2015;121:1-8.

23. Facchini PJ, Luca VD. Expression in escherichia coli and partial characterization of two tyrosine/dopa decarboxylases from opium poppy. Phytochemistry. 1995;38(5):1119-26.

24. Giardina G, Montioli R, Gianni S, Cellini B, Paiardini A, Voltattorni CB, Cutruzzola F. Open conformation of human DOPA decarboxylase reveals the mechanism of PLP addition to group II decarboxylases. P Natl Acad Sc USA. 2011;108(51):20514-9.

25. Paiardini A, Giardina G, Rossignoli G, Voltattorni CB, Bertoldi M. New insights emerging from recent investigations on human group II pyridoxal 5'phosphate decarboxylases. Curr Med Chem. 2017:24(3):226-44.

26. Burrell M, Hanfrey C, Murray EJ, Stanleywall NR, Michael AJ. Evolution and multiplicity of arginine decarboxylases in polyamine biosynthesis and essential role in Bacillus subtilis biofilm formation. J Biol Chem. 2010;285(50): 39224-38.

27. Choudhuri MM, Ghosh B. Purification and partial characterization of arginine decarboxylase from rice embryos (Oryza sativa L.). Agric Biol Chem. 1982; 46(3):739-43.

28. Zhu H, Xu G, Zhang K, Kong X, Han R, Zhou J, Ni Y. Crystal structure of tyrosine decarboxylase and identification of key residues involved in conformational swing and substrate binding. Sci Rep. 2016;6(1):10.

29. Konagaya Y, Kimura B, Ishida M, Fujii T. Purification and properties of a histidine decarboxylase from Tetragenococcus muriaticus, a halophilic lactic acid bacterium. J Appl Microbiol. 2002;92(6):1136-42.

30. Chang C, Zhang J, Ma S, Wang L, Wang D, Zhang J, Gao Q. Purification and characterization of glutamate decarboxylase from Enterococcus raffinosus TCCC11660. J Ind Microbiol Biotechnol. 2017;44(6):817-24.

31. Lim HS, Seo D, Cha I, Lee H, Nam Y, Seo M. Expression and characterization of glutamate decarboxylase from Lactobacillus brevis HYE1 isolated from kimchi. World J Microbiol Biotechnol. 2018;34(3):44.

32. Liu Q, Cheng H, Ma X, Xu N, Liu J, Ma Y. Expression, characterization and mutagenesis of a novel glutamate decarboxylase from Bacillus megaterium. Biotechnol Lett. 2016:38(7):1107-13.

33. Matsumoto T, Yamaura I, Funatsu M. Purification and properties of glutamate decarboxylase from squash. Agric Biol Chem. 1986;50(6):1413-7.

34. Zhang K, Ni Y. Tyrosine decarboxylase from Lactobacillus brevis: soluble expression and characterization. Protein Expr Purif. 2014;94:7.

35. Komori H, Nitta Y, Ueno H, Higuchi Y. Structural study reveals that Ser-354 determines substrate specificity on human histidine decarboxylase. J Biol Chem. 2012;287(34):29175-83.

36. Ma H, Fan X, Cai N, Zhang D, Zhao G, Wang T, Su R, Yuan M, Ma Q, Zhang C, et al. Efficient fermentative production of L-theanine by Corynebacterium glutamicum. Appl Microbiol Biotechnol. 2020;104(1):119-30.

37. Chen J, Zheng C, Ma J, Jiang C, Ercisli S, Yao M, Chen L. The chromosomescale genome reveals the evolution and diversification after the recent tetraploidization event in tea plant. Hortic Res. 2020;7:63.

\section{Publisher's Note}

Springer Nature remains neutral with regard to jurisdictional claims in published maps and institutional affiliations.

Ready to submit your research? Choose BMC and benefit from:
- fast, convenient online submission
- thorough peer review by experienced researchers in your field
- rapid publication on acceptance
- support for research data, including large and complex data types
- gold Open Access which fosters wider collaboration and increased citations
- maximum visibility for your research: over 100M website views per year
At BMC, research is always in progress.
Learn more biomedcentral.com/submissions

